\title{
Parasites of South African wildlife. XIX. The prevalence of helminths in some common antelopes, warthogs and a bushpig in the Limpopo province, South Africa
}

\author{
Authors: \\ Ilana C. van Wyk ${ }^{1}$ \\ Joop Boomker ${ }^{1}$ \\ Affiliations: \\ ${ }^{1}$ Department of Veterinary \\ Tropical Diseases, University \\ of Pretoria, South Africa \\ Correspondence to: \\ Ilana van Wyk \\ Email: \\ ilana@conradie.net \\ Postal address: \\ Private bag $\mathrm{X04}$ \\ Onderstepoort 0110, \\ South Africa \\ Dates: \\ Received: 20 Nov. 2010 \\ Accepted: 29 Aug. 2011 \\ Published: 11 Nov. 2011 \\ How to cite this article: \\ Van Wyk, I.C. \& Boomker, \\ J., 2011, 'Parasites of South \\ African wildlife. XIX. The \\ prevalence of helminths in \\ some common antelopes, \\ warthogs and a bushpig \\ in the Limpopo province, \\ South Africa', Onderstepoort \\ Journal of Veterinary \\ Research 78(1), Art. \#308, \\ 11 pages. $\mathrm{http}: / / \mathrm{dx}$.doi. \\ org/10.4102/ojvr.v78i1.308
}

(C) 2011. The Authors. Licensee: AOSIS OpenJournals. This work is licensed under the Creative Commons Attribution License.
Little work has been conducted on the helminth parasites of artiodactylids in the northern and western parts of the Limpopo province, which is considerably drier than the rest of the province. The aim of this study was to determine the kinds and numbers of helminth that occur in different wildlife hosts in the area as well as whether any zoonotic helminths were present. Ten impalas (Aepyceros melampus), eight kudus (Tragelaphus strepsiceros), four blue wildebeest (Connochaetes taurinus), two black wildebeest (Connochaetes gnou), three gemsbok (Oryx gazella), one nyala (Tragelaphus angasii), one bushbuck (Tragelaphus scriptus), one waterbuck (Kobus ellipsiprymnus), six warthogs (Phacochoerus aethiopicus) and a single bushpig (Potamochoerus porcus) were sampled from various localities in the semi-arid northern and western areas of the Limpopo province.

New host-parasite associations included Trichostrongylus deflexus from blue wildebeest, Agriostomum gorgonis from black wildebeest, Stilesia globipunctata from the waterbuck and Fasciola hepatica in a kudu. The mean helminth burden, including extra-gastrointestinal helminths, was 592 in impalas, 407 in kudus and blue wildebeest, 588 in black wildebeest, 184 in gemsbok, and 2150 in the waterbuck. Excluding Probstmayria vivipara, the mean helminth burden in warthogs was 2228 and the total nematode burden in the bushpig was 80 . The total burdens and species richness of the helminths in this study were consistently low when compared with similar studies on the same species in areas with higher rainfall. This has practical implications when animals are translocated to areas with higher rainfall and higher prevalence of helminths.

\section{Introduction}

Game ranching constitutes a significant part of the land use practices in the Limpopo province, South Africa. Parasites play an important role in regulating host populations in a natural environment; therefore, knowledge about the helminth infections of wildife in an area is essential. Farming with game creates an unnatural system and disrupts the balance between parasite and host. In this stressful environment animals become diseased or can even die from parasite loads that they would have survived under natural conditions. Trophy hunting and the production of venison are increasing in the province and condemnation of carcasses due to macroscopic pathology caused by parasites can lead to financial losses.

Little work has been conducted on the helminth parasites of artiodactylids in the northern and western parts of the province. The aims of this study were to determine the species and numbers of helminth that occur in different wildlife hosts in the area, and to determine whether any zoonotic helminths were present. To this end, a total of 37 animals from various localities in the Limpopo province were examined and their parasites identified and counted.

\section{Materials and methods Materials}

The animal species, number of collections and the collection dates and localities (with their global positioning system coordinates) are summarised in Table 1.

\section{Survey areas}

The survey was performed in the northern parts of the Limpopo province near the Soutpansberg and the town Musina, which lies on the Limpopo River, and the western parts near the town Lephalale. The vegetation in the Soutpansberg region is Mixed Bushveld with sections falling within the mist belt on the escarpment. The Musina area is semi-arid and the vegetation type 
varies between Thornveld and Mopani veld (Acocks 1988). The rainfall recorded between July 2006 and June 2007 for the Soutpansberg area and Musina was $300 \mathrm{~mm}$ and $500 \mathrm{~mm}$, respectively (South African Weather Service 2007). Rainfall is strictly confined to the summer. The climate is hot during summer and cool during winter, with occasional frost.

The western parts of the province are semi-arid and the vegetation type varies between Sweet Bushveld and Mixed Bushveld (Acocks 1988). Rainfall from July 2006 to July 2007 in the Lephalale area was $178 \mathrm{~mm}$ (South African Weather Service 2007). The summers are hot and the winters cool.

\section{Study animals}

With the exception of one gemsbok (Oryx gazella) and the nyala (Tragelaphus angasii), the study material was obtained from animals that had been culled or hunted during the hunting season (May-September) of 2006 and 2007. A few organ samples from one of the gemsbok and the carcass of the nyala were submitted to the Louis Trichardt Veterinary Laboratory for post-mortem examination.
In addition to the warthogs (Phacochoerus aethiopicus) that had been culled, the carcasses of several warthogs from a meat processing plant were examined for Trichinella spp. As only the eviscerated carcasses were available, only samples from the diaphragms and the intercostal muscles could be collected for examination.

\section{Collection and preservation of parasites}

The carcasses of the culled animals were first inspected visually for the presence of Taenia or Echinococcus metacestodes on the cut surfaces and those of the pericardium, heart, diaphragm and liver. When permitted, the tongue was freed and examined visually and palpated. Only single metacestodes were encountered and collected, which were subsequently preserved in $70 \%$ alcohol.

Carcasses that were destined for export were not skinned until they reached the abattoir. No incisions were made into the muscles, except for the masseter and the diaphragm. The heads and capes of animals hunted for trophies were preserved; therefore, no incisions of the masseter muscles or tongues could be made.

TABLE 1: The collection data for the various animals examined.

\begin{tabular}{|c|c|c|c|c|c|}
\hline Species & $n$ & Date & Locality & Farm & GPS coordinates \\
\hline \multirow[t]{5}{*}{ Impala } & 3 & Jun. 2006 & \multirow[t]{2}{*}{ Musina } & \multirow[t]{2}{*}{ Musina Research Station } & \multirow{2}{*}{$\begin{array}{l}22^{\circ} 40.645 \mathrm{~S} \\
29^{\circ} 48.895 \mathrm{E}\end{array}$} \\
\hline & 1 & Jul. 2007 & & & \\
\hline & 1 & Jun. 2006 & Musina & Kerneels Young Trust & $\begin{array}{l}22^{\circ} 40.645 \mathrm{~S} \\
29^{\circ} 48.895 \mathrm{E}\end{array}$ \\
\hline & 2 & Jun. 2006 & Lephalale & Bushman's Safaris & $\begin{array}{l}23^{\circ} 10.086 \mathrm{~S} \\
28^{\circ} 05.189 \mathrm{E}\end{array}$ \\
\hline & 3 & Aug. 2007 & Soutpansberg & Nwanedi Nature Reserve & $\begin{array}{l}22^{\circ} 56.129 \mathrm{~S} \\
29^{\circ} 55.003 \mathrm{E}\end{array}$ \\
\hline \multirow[t]{5}{*}{ Kudu } & 3 & May 2007 & Soutpansberg & Langgedachte & $\begin{array}{l}23^{\circ} 19.985 \mathrm{~S} \\
29^{\circ} 48.075 \mathrm{E}\end{array}$ \\
\hline & 2 & Jul. 2007 & Musina & Musina Research Station & $\begin{array}{l}22^{\circ} 40.645 \mathrm{~S} \\
29^{\circ} 48.895 \mathrm{E}\end{array}$ \\
\hline & 1 & Jun. 2006 & Musina & Kerneels Young Trust & $\begin{array}{l}22^{\circ} 40.645 \mathrm{~S} \\
29^{\circ} 48.895 \mathrm{E}\end{array}$ \\
\hline & 1 & Jul. 2007 & Lephalale & Bushman's Safaris & $\begin{array}{l}23^{\circ} 10.086 \mathrm{~S} \\
28^{\circ} 05.189 \mathrm{E}\end{array}$ \\
\hline & 1 & Aug. 2007 & Soutpansberg & Nwanedi Nature Reserve & $\begin{array}{l}22^{\circ} 56.129 \mathrm{~S} \\
29^{\circ} 55.003 \mathrm{E}\end{array}$ \\
\hline Bushbuck & 1 & Aug. 2007 & Soutpansberg & Last Post & $\begin{array}{l}23^{\circ} 17.557 \mathrm{~S} \\
29^{\circ} 54.593 \mathrm{E}\end{array}$ \\
\hline Nyala & 1 & Sep. 2007 & Soutpansberg & Uitvlught & $\begin{array}{l}23^{\circ} 02.903 \mathrm{~S} \\
29^{\circ} 46.035 \mathrm{E}\end{array}$ \\
\hline \multirow[t]{2}{*}{ Blue wildebeest } & 3 & Aug. 2007 & Soutpansberg & Langgedachte & $\begin{array}{l}23^{\circ} 19.985 \mathrm{~S} \\
29^{\circ} 48.075 \mathrm{E}\end{array}$ \\
\hline & 1 & Jul. 2006 & Lephalale & Bushman's Safaris & $\begin{array}{l}23^{\circ} 10.086 \mathrm{~S} \\
28^{\circ} 05.189 \mathrm{E}\end{array}$ \\
\hline Black wildebeest & 2 & Jul. 2007 & Lephalale & Bushman's Safaris & $\begin{array}{l}23^{\circ} 10.086 \mathrm{~S} \\
28^{\circ} 05.189 \mathrm{E}\end{array}$ \\
\hline \multirow[t]{2}{*}{ Gemsbok } & 2 & Jul. 2007 & Musina & Musina Research Station & $\begin{array}{l}22^{\circ} 40.645 \mathrm{~S} \\
29^{\circ} 48.895 \mathrm{E}\end{array}$ \\
\hline & 1 & Jun. 2006 & Musina & Kerneels Young Trust & $\begin{array}{l}22^{\circ} 40.645 \mathrm{~S} \\
29^{\circ} 48.895 \mathrm{E}\end{array}$ \\
\hline Waterbuck & 1 & Jul. 2007 & Soutpansberg & Last Post & $\begin{array}{l}23^{\circ} 17.557 \mathrm{~S} \\
29^{\circ} 54.593 \mathrm{E}\end{array}$ \\
\hline \multirow[t]{4}{*}{ Warthog } & 2 & Aug. 2006 & \multirow[t]{2}{*}{ Lephalale } & \multirow[t]{2}{*}{ Bushman's Safaris } & \multirow{2}{*}{$\begin{array}{l}23^{\circ} 10.086 \mathrm{~S} \\
28^{\circ} 05.189 \mathrm{E}\end{array}$} \\
\hline & 2 & Aug. 2007 & & & \\
\hline & 1 & Jun. 2006 & Musina & Kerneels Young Trust & $\begin{array}{l}22^{\circ} 40.645 \mathrm{~S} \\
29^{\circ} 48.895 \mathrm{E}\end{array}$ \\
\hline & 1 & Jun. 2007 & Musina & Alldays & $\begin{array}{l}22^{\circ} 45.639 \mathrm{~S} \\
29^{\circ} 48.523 \mathrm{E}\end{array}$ \\
\hline Bushpig & 1 & Oct. 2007 & Soutpansberg & Soekmekaar & $\begin{array}{l}23^{\circ} 17.557 \mathrm{~S} \\
29^{\circ} 54.593 \mathrm{E}\end{array}$ \\
\hline
\end{tabular}

GPS, global positioning system; $n$, sample size. 
The intestinal helminths as well as those in the heart, lungs and liver of the antelopes were collected as described by Boomker, Horak and De Vos (1989) but digests of abomasal and intestinal mucosae were not performed. Depending on the volume of ingesta of the different parts of the gastrointestinal tract, aliquots of a quarter, a tenth or a 25 th were made and examined. The entire abomasal content of the bushbuck (Tragelaphus scriptus) was examined.

The helminths of warthogs and the bushpig (Potamochoerus porcus) were recovered as described by Boomker et al. (1991a). In addition, muscle samples from the diaphragm and intercostal and masseter muscles were crushed (between glass slides) and examined under a stereoscopic microscope for the presence of Trichinella spp.

\section{Parasite counts and identification}

Aliquots of ingesta and organ washings were fixed and preserved in $70 \%$ ethyl alcohol. These were transported to the laboratory, where they were examined under a stereoscopic microscope and all helminths were removed. The nematodes were cleared in lactophenol, identified under a standard microscope and counted. Male nematodes were identified to species level, whereas female nematodes, especially where two or more related species occurred in a single host, were identified to the generic level only. Fourth-stage larvae were identified only to the generic level.

Live adult cestodes were relaxed in water in Petri dishes. Once all movement had ceased they were fixed in 5\% formalin for $24 \mathrm{~h}$ and further preserved in 70\% ethyl alcohol. Scoleces were dissected out of the metacestodes and mounted en face in Berlese's fluid under slight pressure from a cover slip. Adult cestodes were stained in carmalum or Mayer's acid haemalum, cleared in xylene and mounted on glass slides in Canada balsam (Gibbons, Jones \& Kahlil 1996).

\section{Data analysis}

Sampling was not truly random and depended on circumstances to some extent. Therefore, the significance of the results could not be compared statistically. However, descriptive statistics were used as applicable.

\section{Ethical considerations}

The samples in this study were opportunistically collected from animals that had been either hunted or culled for reasons other than this study.

\section{Results and discussion \\ Animals \\ Impalas}

Twelve helminth species, ten nematodes and two cestodes were recovered from impalas (Aepyceros melampus) in this study. The helminth burdens are presented in Table 2.

Cooperia hungi was most prevalent, followed by Impalaia tuberculata, Oesophagostomum columbianum and Trichostrongylus deflexus. Haemonchus krugeri had the highest mean intensity (375 worms), followed by C. hungi (280 worms) and I. tuberculata (140 worms).

Impala and their parasites have been studied by several authors and some significant contributions have been made by Anderson (1992), Heinichen (1973), Horak (1978, 1980, 1981) and Mönnig (1933) in South Africa and Gallivan et al. (1989) in Swaziland. Because of their feeding ecology, impala are exposed to the helminths of both browsers and grazers. Impala also share pastures with domestic livestock on many game ranches in South Africa and considerable overlap between the helminth fauna of sheep, cattle and impalas occurs (Horak 1978).

TABLE 2: Total helminth burdens of examined impala.

\begin{tabular}{|c|c|c|c|c|c|c|c|c|c|c|c|c|}
\hline \multirow[t]{2}{*}{ Species } & \multicolumn{3}{|c|}{ Lephalale area } & \multicolumn{4}{|c|}{ Musina area } & \multicolumn{3}{|c|}{ Soutpansberg area } & \multirow{2}{*}{$\begin{array}{c}\text { Mean } \\
(n=10)\end{array}$} & \multirow{2}{*}{$\begin{array}{c}\text { Prevalence } \\
(\%)\end{array}$} \\
\hline & $\mathrm{BI} 1 \uparrow$ & $\mathrm{B} 12 \uparrow$ & $\mathrm{BI}+$ & $\mathrm{MI} 1 \dagger$ & $\mathrm{MI} 2 \dagger$ & $\mathrm{MI} 3 \dagger$ & YI1† & Nwl1† & $\mathrm{Nwl2 \dagger}$ & $\mathrm{Nw} 3 \dagger$ & & \\
\hline Cooperia fuelleborni & - & - & - & - & - & 75 & - & - & - & - & 7 & 10 \\
\hline Cooperia hungi & 150 & 100 & - & 75 & 500 & 25 & 450 & 475 & 475 & 275 & 253 & 90 \\
\hline Cooperia L4 & - & - & - & - & - & - & 200 & - & - & - & 20 & 10 \\
\hline Cooperioides hamiltoni & 200 & 75 & - & - & - & - & - & - & - & - & 28 & 20 \\
\hline Cooperioides hepaticae & - & - & - & - & - & - & - & 10 & - & 20 & 3 & 20 \\
\hline Haemonchus krugeri & 350 & - & 400 & - & - & - & - & - & - & - & 75 & 20 \\
\hline Haemonchus L4 & 25 & - & - & 25 & - & - & - & - & - & - & 5 & 20 \\
\hline Impalaia tuberculata & - & 75 & - & - & - & - & 225 & 325 & 25 & 50 & 70 & 50 \\
\hline Impalaia $\mathrm{L4}$ & 225 & - & - & - & - & - & - & - & - & - & 23 & 10 \\
\hline Longistrongylus sabie & - & - & - & - & - & 50 & - & - & - & - & 5 & 10 \\
\hline Oesophagostomum columbianum & 125 & 25 & 250 & - & 25 & - & - & 25 & - & - & 40 & 50 \\
\hline Oesophagostomum L4 & - & - & - & - & - & - & - & 225 & - & - & 23 & 10 \\
\hline Trichostrongylus colubriformis & - & - & - & - & - & - & - & - & 150 & 25 & 18 & 20 \\
\hline Moniezia expansa & - & - & - & - & 5 & - & - & - & - & - & 1 & 10 \\
\hline Stilesia hepatica & - & - & - & - & - & - & - & - & - & 7 & 1 & 10 \\
\hline Total burden & 1100 & 300 & 650 & 25 & 550 & 250 & 875 & 1100 & 650 & 377 & 588 & - \\
\hline
\end{tabular}

L4, fourth-stage larvae.

$\dagger$, Individual animal number. 
Cooperia hungi is considered a definitive parasite of impalas and the other nine nematode species all occurred in five or fewer animals, which classifies them as either occasional or accidental parasites (Horak 1980).

In Horak's (1978) study on impala at Nylsvley, more than $90 \%$ of the worms were retarded in the fourth stage at different times of the year. As digests were not carried out in this study, the recovery rate of larval stages was low, which may account for the low total helminth counts. The harsh environment in the northern and western parts of the Limpopo province would necessitate helminth parasites to employ strategies to protect the vulnerable, free-living larval stages, not only during winter when temperatures and rainfall are low, but also during summer, when temperatures are high and rainfall often low. Owing to the higher rainfall and milder climate at Nylsvley it is doubtful whether the same levels of larval retardation exist for worms in the current study area.

The relatively few helminth species recovered could also be due to a smaller diversity of antelope species in the sampling areas. Where a large number of antelope species are present, cross-transmission can take place more readily (Boomker, Anthonissen \& Horak 1988), which increases the diversity of parasite species.

Although two impalas from Nwanedi in the Soutpansberg had eosinophilic granulomata in the lungs, no parasites were recovered from these lesions. The most common gross lesions associated with the lungworm Pneumostrongylus calcaratus in impalas in Swaziland were firm nodules along the lateral borders of the caudal lung lobes (Gallivan et al. 1989). Those authors recorded an $85 \%$ prevalence of this nematode in impalas in Mlawula Nature Reserve, Swaziland. Pneumostrongylus calcaratus has been found to be prevalent in the eastern Transvaal Lowveld (now Limpopo and Mpumalanga) as indicated by Ortlepp (1962) and Young and Wagener (1968), and in the northern part of KwaZuluNatal (Anderson 1992). Young and Wagener (1968) found a high prevalence in impala in the southern Kruger National Park, whereas Horak $(1978,1980)$ did not recover lungworms from impalas at Nylsvley Nature Reserve or from Pafuri in the northern Kruger National Park. Horak (1981) ascribed this difference in prevalence to climate. He suggested that Pneumostrongylus is restricted to warm, moist regions, where the mollusk intermediate host (Urocyclus [Elisolimax] flavescens) occurs.

\section{Kudus}

Five nematode species and one trematode were recovered from kudus (Tragelaphus strepsiceros) in this study. The total worm burdens are summarised in Table 3.

The kudu with the highest burden had 2690 worms, of which 2425 were Haemonchus contortus. Excluding this kudu, the mean burden for the remaining seven kudus was 81 worms. This is a classical example of overdispersion of the parasites.
The lowest burden was six worms, comprising the two species Elaeophora sagitta and Fasciola hepatica, which both use intermediate hosts. The mean helminth burden, including $E$. sagitta and F. hepatica, was 407 worms.

Haemonchus contortus was the most prevalent worm and was recovered from six of the eight kudus, followed by E. sagitta recovered from three kudus.

According to the criteria of Horak (1980), Haemonchus vegliai, Cooperia neitzi, Cooperia acutispiculum, E. sagitta and T. deflexus are definitive parasites of kudus in the Kruger National Park (Boomker et al. 1989) and in the Eastern Cape (Boomker, Horak \& Knight 1991b). The amphistomes, Schistosoma mattheei, Moniezia benedeni, Taenia larvae, I. tuberculata, Agriostomum gorgonis and Strongyloides papillosus are considered occasional parasites in kudu (Boomker et al. 1991b).

Kudus are known to harbour parasites from other species of antelopes. Boomker et al. (1991b) found that kudus in the Addo Elephant National Park harboured Nematodirus helvetianus and Dictyocaulus spp., thought to originate from cattle in the area. The $H$. contortus recovered in the current study probably originated from goats. Cooperioides hamiltoni, a parasite described from impalas, was recovered from kudus in this study and is considered an occasional parasite of kudus (Boomker et al. 1988).

Except for one kudu from the Soutpansberg area, the helminth burdens were relatively low but the range was similar for that of kudu sampled in the Etosha Game Reserve (Boomker et al. 1988) and the Eastern Cape (Boomker et al. 1991b). This is in contrast to kudus sampled in the Kruger National Park (Boomker et al. 1989), which showed much higher burdens. The kudus were mainly from the southern region of the park, which has an annual rainfall of $600 \mathrm{~mm}-$ $700 \mathrm{~mm}$. The dry climate of the localities in the present study area is more similar to that in Etosha and the Eastern Cape and is too harsh for the survival of the free-living infective stages of helminths (Boomker et al. 1989).

Of the helminths considered definitive parasites of kudu in the Kruger National Park (Boomker et al. 1989) only C. neitzi and $E$. sagitta were recovered from the kudus in this study. However, C. neitzi was recovered only in one kudu and in small numbers. Elaeophora sagitta was recovered from three kudus from two of the localities in this study and also not in significant numbers. Their presence is an indication of the abundance of their intermediate host (Boomker 2007).

Because kudus are browsers and roam considerably they are subject to reinfection with their own parasites only to a limited extent (Boomker, Horak \& De Vos 1986). However, animals that roam are more likely to become infected with accidental parasites (Horak 1980). Agriostomum gorgonis and Oesophagostomum spp. are considered accidental parasites as they occurred only in one kudu each and in low numbers.

\section{Bushbuck}

No parasites were recovered from the single animal recovered in this survey. This may be a result of underdispersion or 
the low stocking densities of antelopes on the farm of origin, which, in turn, will also limit the exposure of animals to infection or cross-infection with helminths.

\section{Nyala}

The carcass of the nyala bull was submitted to the Louis Trichardt Veterinary Laboratory for a post-mortem examination in October 2007. Clostridium novyi was diagnosed as the cause of death. The animal was in poor condition and died during the rutting season. It was expected that the animal would have harboured some parasites under these conditions, yet none was recovered. The nyala originated from a farm where cattle and antelopes shared the same pasture. Deworming of cattle could be a possible reason for the absence of helminths as the parasite contamination on the pasture would be reduced. Also, the nyala died at the end of the dry season, before the first spring rains, when larvae were still in hypobiosis or absent from the pasture.

\section{Blue wildebeest}

Five nematode species were recovered from blue wildebeest (Connochaetus taurinus) in this study and their burdens are summarised in Table 4.

The highest total burden in an animal was 550 worms. The mean helminth burden of the four blue wildebeest was 407 worms. The species with the highest intensity was H. contortus (500 per individual), followed by Haemonchus bedfordi (375 per individual). This parasite appears to be common in blue wildebeest and has been recovered from animals from the Kruger National Park (Horak, De Vos \& Brown 1983b) as well as from the Kalahari Gemsbok National Park (now Kgalagadi Transfrontier Park) (Boomker et al. 1986).

Cooperia connochaeti was recovered from three of the four blue wildebeest in this study. It is considered a definitive parasite for this species.
The seasonal patterns of several parasites of wildebeest from the Kruger National Park have been attributed to a combination of climatic factors and migratory patterns of the wildebeest in the park (Horak et al. 1983b). On small game farms animals generally have limited migration patterns and therefore the risk of becoming reinfected from the contaminated pastures increase.

\section{Black wildebeest}

One of the two black wildebeest (Connochaetes gnou) sampled harboured $100 \mathrm{H}$. bedfordi only. The other presented with a total of 1075 worms, comprising 50 A. gorgonis, 875 H. bedfordi and 150 O. columbianum.

The helminths of black wildebeest have received little attention (Boomker et al. 2000). Wildebeest appear to be fairly resistant to parasitic infections, as animals from the Golden Gate Highlands National Park and Rietvlei Nature Reserve harboured relatively low burdens of only a small number of helminth species when compared with blue wildebeest from the Kruger National Park (Horak et al. 1983b). In an earlier study, Boomker et al. (2000) found that a black wildebeest from the Mountain Zebra National Park harboured a single Taenia sp. larva, 26 Haemonchus spp. females and one Haemonchus spp. larva. Neither of two black wildebeest from the Karoo National Park sampled during that study harboured any worms (Boomker et al. 2000).

\section{Gemsbok}

Two nematode species and the larval stages of two cestode species were recovered from the gemsbok sampled in the present study. One of the two gemsbok from Musina had 350 C. hungi, one Setaria hornbyi and seven Taenia hydatigena larvae, whilst the other had no nematodes and only six $T$. hydatigena and three Taenia hyaenae larvae. The gemsbok from

TABLE 3: Total helminth burdens of examined kudu.

\begin{tabular}{|c|c|c|c|c|c|c|c|c|c|c|}
\hline \multirow[t]{2}{*}{ Species } & \multicolumn{4}{|c|}{ Soutpansberg area } & \multirow{2}{*}{$\begin{array}{c}\text { Lephalale } \\
\text { BK1† }\end{array}$} & \multicolumn{3}{|c|}{ Musina area } & \multirow{2}{*}{$\begin{array}{r}\text { Mean } \\
(n=8)\end{array}$} & \multirow{2}{*}{$\begin{array}{c}\text { Prevalence } \\
(\%)\end{array}$} \\
\hline & VK1† & VK2 $†$ & VK3† & NwK1 $\uparrow$ & & YK1† & мк1† & MK2† & & \\
\hline Agriostomum gorgonis & - & - & 25 & - & - & - & - & - & 3 & 12.5 \\
\hline Cooperia neitzi & - & - & 240 & - & - & - & - & - & 30 & 12.5 \\
\hline Elaeophora sagitta & - & - & - & 4 & - & - & 85 & 1 & 12 & 37.5 \\
\hline Haemonchus contortus & 50 & 275 & 2425 & - & 50 & - & 50 & 25 & 359 & 75.0 \\
\hline Oesophagostomum L4 & - & - & - & - & - & 25 & - & - & 3 & 12.5 \\
\hline Fasciola hepatica & - & - & - & 2 & - & - & - & - & 0 & 12.5 \\
\hline Total burden & 50 & 275 & 2690 & 6 & 50 & 25 & 135 & 26 & 407 & - \\
\hline
\end{tabular}

L4, fourth-stage larvae.

$\dagger$, Individual animal number

TABLE 4: Total helminth burdens of examined blue wildebeest.

\begin{tabular}{|c|c|c|c|c|c|c|}
\hline \multirow[t]{2}{*}{ Species } & \multicolumn{3}{|c|}{ Soutpansberg area } & \multirow{2}{*}{$\begin{array}{c}\text { Lephalale } \\
\text { BWB1† }\end{array}$} & \multirow{2}{*}{$\begin{array}{c}\text { Mean } \\
(n=4)\end{array}$} & \multirow{2}{*}{$\begin{array}{c}\text { Prevalence } \\
(\%)\end{array}$} \\
\hline & VWB1† & VWB2† & VWB3† & & & \\
\hline Cooperia connochaeti & 75 & 175 & - & 125 & 94 & 75 \\
\hline Haemonchus bedfordi & - & - & - & 375 & 94 & 25 \\
\hline Haemonchus contortus & 100 & 175 & 500 & - & 194 & 75 \\
\hline Oesophagostomum columbianum & - & - & - & 50 & 12 & 25 \\
\hline Trichostrongylus deflexus & 25 & - & 25 & - & 12 & 50 \\
\hline Moniezia benedeni & - & - & fragments & - & - & 25 \\
\hline Total burden & 200 & 350 & 525 & 550 & 407 & - \\
\hline
\end{tabular}

$\dagger$, Individual animal number. 
Kerneels Young Trust harboured three calcified Setaria spp. and two T. hydatigena larvae.

The larval stages of $T$. hydatigena were found attached to the mesenterium and liver of all three gemsbok. The $T$. hyaenae larvae occurred in the triceps and heart muscles. The metacestodes were identified according to the number and size of their rostellar hooks (Verster 1969).

Although gemsbok are relatively common in the Limpopo province, they are historically not endemic to this region. The translocation of antelopes to climatic or vegetation regions where they did not occur historically can be hazardous to their health (Boomker et al. 2000). Earlier studies found the total helminth burden of gemsbok from the West Coast National Park, where the antelopes do not naturally occur, to be 28681 (Boomker et al. 2000), compared with 5877 for gemsbok from the Kalahari Gemsbok National Park (now Kgalagadi Trasfrontier Park) (Boomker et al. 1986). The high burden for gemsbok in the West Coast National Park is attributed to the climatic conditions in the area, as the climate appeared to favour parasites but caused stress in the gemsbok (Boomker et al. 2000). In the Limpopo province the climate is rather similar to that of the Kalahari, which may be the reason for the small numbers of helminths recovered from gemsbok in the present study.

\section{Waterbuck}

Five helminth species were recovered from the waterbuck (Kobus ellipsiprymnus), namely Cooperia curticei, Trichuris spp., O. columbianum, Avitellina spp. and Stilesia globipunctata. The helminth with the highest intensity was C. curticei (2075), followed by Trichuris spp. (50) and O. columbianum (25). This is approximately half of what was recovered from a single waterbuck from Pretoriuskop in the Kruger National Park, which harboured 4082 helminths (Boomker et al. 1986) and included H. bedfordi (813), Cooperia fuelleborni (1524), C. hungi (363), Cooperia yoshidai (1088), I. tuberculata (225) and O. columbianum (25) (Boomker et al. 1986).

\section{Warthogs}

Ten helminth species were recovered from the warthogs in this study. The total burdens of each parasite are presented in Table 5.
Two nematode genera occurred in all the warthogs, namely Oesophagostomum mwanzae and Probstmayria vivipara. Murshidia hamata was recovered from four of the six warthogs and Oesophagostomum mocambiquei from three. Murshidia pugnicaudata was recovered from only two warthogs. Hydatid cysts of Echinococcus granulosus were recovered from the lungs of one of the warthogs.

The helminth with the highest intensity was $P$. vivipara, with burdens ranging between 276000 and 825000 per host. The helminth with the second highest intensity was O. mwanzae, with a total burden of 3700 recovered from one warthog.

The highest total helminth burden that included $P$. vivipara, was 825940 including for warthog BWh1. However, warthog BWh3 had the highest helminth burden (5920) that excluded P. vivipara.

No Trichinella were found in any of the carcasses.

Four of the warthogs originated from Bushman's Safaris, two of which were examined in August 2006 and two in August 2007. The two warthogs from the 2006 sample harboured Murshidia spp. but no O. mocambiquei, but the converse was true for the warthogs examined in 2007. The two warthogs sampled in 2006 also had lower total helminth burdens (excluding P. vivipara), namely 162 and 702, respectively. The warthogs sampled in 2007 had total burdens (excluding P. vivipara) of 5920 and 4810 , respectively. It is possible that although Lephalale had below-average rainfall during the 2006/2007 season, rain during the dry season in 2007 could have affected the abundance of parasites in the region.

The helminths of warthogs in southern Africa have been described by several authors, including Boomker et al. (1991a), Horak et al. (1983a, 1988) and Ortlepp (1964). The helminth parasites of warthogs as listed by Round (1968) include parasites from across Africa. However, many helminths occur only in certain regions as is evident from the work of Ortlepp (1964), Horak et al. (1983a, 1988) and Boomker et al. (1991a).

TABLE 5: Total helminth burdens of examined warthogs.

\begin{tabular}{|c|c|c|c|c|c|c|c|c|}
\hline \multirow[t]{2}{*}{ Species } & \multicolumn{2}{|c|}{ Musina } & \multicolumn{4}{|c|}{ Lephalale } & \multirow{2}{*}{$\begin{array}{l}\text { Mean } \\
(n=6)\end{array}$} & \multirow{2}{*}{$\begin{array}{c}\text { Prevalence } \\
(\%)\end{array}$} \\
\hline & YWh1† & AWh1† & BWh1 $\uparrow$ & $\mathrm{BWh2 \dagger}$ & BWh3† & BWh4† & & \\
\hline Cooperia hungi & 4 & - & - & - & - & - & 0 & 17 \\
\hline Impalaia tuberculata & - & - & - & 12 & - & - & 2 & 17 \\
\hline Murshidia hamata & 50 & 90 & 90 & 250 & - & - & 80 & 67 \\
\hline Murshidia pugnicaudata & 35 & - & - & 80 & - & - & 20 & 33 \\
\hline Oesophagostomum mocambiquei & - & 380 & - & - & 2300 & 1100 & 1064 & 50 \\
\hline Oesophagostomum mwanzae & 1075 & 130 & 850 & 350 & 3600 & 3700 & 1185 & 100 \\
\hline Probstmayria vivipara & 276000 & 380000 & 825000 & 407000 & 648000 & 470000 & 501000 & 100 \\
\hline Physocephalus sexalatus & 3 & - & 27 & 13 & 20 & 9 & 12 & 83 \\
\hline Echinococcus sp. cyst & - & - & - & - & - & 1 & 0 & 17 \\
\hline Paramonezia phacochoeri & - & - & - & 1 & - & - & 0 & 17 \\
\hline Total helminth burden & 277167 & 38600 & 825967 & 407706 & 653920 & 474810 & 50335 & - \\
\hline Total burden excluding $P$. vivipara & 1167 & 600 & 967 & 706 & 5920 & 4810 & 2363 & - \\
\hline
\end{tabular}

$\uparrow$, Individual animal number. 


\section{Bushpig}

A total of 80 worms representing two nematode species, namely Physocephalus sexalatus (10) and Globocephalus versteri (70), were recovered from the single bushpig.

The total worm burden of the bushpig was low compared with that of warthogs. Ortlepp (1964) made no note of the burdens of the worms he recovered from bushpigs. Because only one animal was examined, a low burden due to underdispersion could not be ruled out.

Little work has been conducted on the helminth parasites of bushpigs. Ortlepp (1964) examined material from Mozambique and the northern Transvaal (now Limpopo), which has been included in the list of helminth parasites of Round (1968). Bushpigs are difficult to sample because of their largely nocturnal activity and their relatively limited distribution in forested areas.

\section{Helminths}

\section{Agriostomum}

Agriostomum gorgonis was recovered only from one kudu and one black wildebeest, and in small numbers from both animals. It is considered an occasional parasite of kudus in the Kruger National Park (Boomker et al. 1989). No record could be found of the worm in black wildebeest, but it has been listed as a parasite of blue wildebeest (Horak et al. 1983b; Round 1968). The free-living stages of hookworms require moist climatic conditions for survival and the low rainfall in the present study area would have been limiting to the survival of the larvae of these parasites.

\section{Cooperia}

Cooperia hungi was recovered from only one warthog in this study. It has previously been recovered from warthogs at Hoedspruit in the eastern Transvaal (now eastern part of the Limpopo province) (Boomker et al. 1991a). It is primarily a parasite of impala (Horak 1978) and is considered an accidental parasite in warthogs (Boomker et al. 1991a).

\section{Cooperioides}

Cooperioides hepaticae is the only extra-intestinal trichostrongyloid of impalas and is considered a common parasite of impalas in the Kruger National Park (Pletcher et al. 1988; Young \& Wagener 1968). Pletcher et al. (1988) suggest that smaller burdens in adult impalas compared with yearlings may be due to acquired partial immunity in adults due to previous exposure. Cooperioides hepaticae is generally considered to be of minor pathological significance unless it is present in large numbers in combination with other trichostrongyles, or when burdens are associated with poor nutritional conditions (Pletcher et al. 1988).

In the present study, C. hepaticae was recovered from only two impalas and both had very small burdens. One reason for the low prevalence and intensity could be that the animals sampled were all adults and thus would have had an acquired immunity. Also, the animals were all sampled before the start of the rainy season and therefore the peak burdens of this parasite might have been missed. The dry climate of the study area will affect the survival of free-living stages of the parasites.

\section{Elaeophora}

Elaeophora sagitta is a definitive parasite of the tragelaphine antelopes (Boomker et al. 1988). This worm was recovered only from three kudus (i.e. none were recovered from the bushbuck or nyala) during the current study. This can be because neither the parasite nor its vector, thought to be a tabanid fly (Boomker et al. 1986), is common in the study area.

\section{Haemonchus}

Haemonchus contortus was the most prevalent worm in kudus in this study. It was recovered from six kudus from three different localities in the study area. Except for one kudu, the individual burdens of the worm was small.

At Langgedachte, $H$. contortus was collected from three blue wildebeest and three kudus. At this game farm, domestic livestock and game are kept together. Haemonchus contortus is considered a parasite of domestic animals and the high prevalence is possibly due to cross-transmission from domestic animals and the high stocking densities on the farm.

\section{Impalaia}

Impalaia tuberculata is a parasite of several antelope species, in particular impalas and blesbok, (Damaliscus dorcas phillipsi) (Boomker 1977; Horak 1978). It was recovered from only one warthog in this study. Warthogs are not considered to be definitive hosts of these parasites (Boomker et al. 1991a; Horak et al. 1988) and infection was probably accidental.

\section{Murshidia}

Ortlepp (1964) recovered M. hamata from Pilgrim's Rest and Zululand, but M. pugnicaudata only from Pilgrim's Rest. No Murshidia spp. have been recovered from warthogs in Namibia (Horak et al. 1983a). Both species have been recovered from warthogs from Hoedspruit (Boomker et al. 1991a) and the Kruger National Park (Horak et al. 1988). Only $M$. hamata has been recovered from warthogs in the northwestern Transvaal (now the Limpopo province) (Boomker et al. 1991a). Between 50 and 250 M. hamata were recovered from four of the warthogs in this study. Murshidia pugnicaudata, however, was recovered in small numbers from only two animals: one from the Musina area in the north and the other from the Lephalale area in the west. Both species therefore occur in the north, east and west of the province, but $M$. pugnicaudata possibly not in the north-west. However, it is not stated from where the warthogs in the north-western Transvaal originated (Boomker et al. 1991a). It should be noted that M. pugnicaudata was recovered only from warthogs examined during 2006. It is possible that climatic factors played a role in the prevalence of the parasites. 


\section{Oesophagostomum}

Oesophagostomum columbianum is a common parasite of many antelope species (Boomker 2007). It was the most prevalent helminth in this study and was recovered from four hosts, namely the waterbuck, blue and black wildebeest, and impalas. In none of these animals did this worm occur in large numbers. The typical lesions in the large intestines of sheep due to O. columbianum infestation were not found in any of the examined animals. Horak (1981) considers $O$. columbianum as a definitive parasite of impala.

Both O. mwanzae and O. mocambiquei have been recovered from warthogs from Hoedspruit (Boomker et al. 1991a), the Kruger National Park (Horak et al. 1988) and Pilgrim's Rest (Ortlepp 1964). Both species were also recovered in this study from animals that originated from the Musina and Lephalale areas. It would appear that these are the only two Oesophagostomum species that occur in warthogs in the Limpopo and Mpumalanga provinces. Although O. mwanzae is the dominant of the two species, both can be considered definitive parasites of warthogs in the area.

\section{Setaria}

Setaria spp. are filarid worms and the adults are usually found in the abdominal cavity of their hosts. Mosquitoes are the intermediate hosts (Reinecke 1983). The Setaria spp. are considered non-pathogenic and are usually found only at necropsy.

\section{Trichostrongylus}

Trichostrongylus deflexus has been described as a separate species only relatively recently (Boomker \& Reinecke 1989). Mönnig (1933) described specimens of Trichostrongylus instabilis from impala with extreme variation in the spicule shape. Similarly, Horak (1980) found the same extreme variation in spicule shape from Trichostrongylus males that he recovered from sheep, calves and goats that had been artificially infected from faecal cultures of impalas. He referred to these worms as Trichostrongylus colubriformis. Boomker and Reinecke (1989) re-evaluated some of these specimens and proposed that these worms represent a definitive species, which they named T. deflexus. Horak et al. (1983b) reported T. colubriformis from blue wildebeest from the Kruger National Park. They made no mention of the spicule morphology. After examining the material collected by Horak et al. (1983b) from the wildebeest, Boomker and Reinecke (1989) considered T. colubriformis from this material as synonymous with $T$. deflexus. Trichostrongylus deflexus was recovered from blue wildebeest and impalas in the current study.

\section{Trichuris}

Ortlepp (1937) described Trichuris barbertonensis from an ox. The spicules and sheath measured between $6.83 \mathrm{~mm}$ and $7.3 \mathrm{~mm}$ and did not end in a bulb or swelling as is described for Trichuris globulosa or Trichuris ovis. Two individual adult Trichuris worms were recovered from the large intestine of the waterbuck in the current study. The spicules of the male measured $5.8 \mathrm{~mm}$ in length and did not end in a bulb or swelling either. It is possible that the specimen collected from the waterbuck was T. barbertonensis.

Many Trichuris spp., of which T. globulosa is the most widespread, have been reported to occur in antelopes in southern Africa (Ortlepp 1937). Trichuris spp. are of greater concern in enclosures and zoos than in open spaces owing to their monoxenous life cycle and thick-shelled eggs (Boomker 2007). Environmental build-up of the parasite is not likely to happen in a free-range system.

\section{Avitellina}

Avitellina spp. is common in semi-arid areas (Reinecke 1983) but was recovered only from the waterbuck.

\section{Stilesia}

Stilesia globipunctata fragments were recovered from the waterbuck. No previous record of this parasite in waterbuck could be found. Both Stilesia and Avitellina require an invertebrate intermediate host, such as oribatid soil mites. Adult worms are therefore more likely to be found in animals that feed close to the ground (Boomker et al. 1986).

In this study Stilesia hepatica was recovered from only one impala. Gallivan et al. (1996) reported no difference between seasons or sexes, but in their study adult animals had larger burdens, possibly indicating that it is an accumulative infection.

\section{Echinococcus}

Hydatid cysts were recovered from the lungs of one warthog. Echinococcus granulosus has remarkably low intermediate host specificity (MacPherson 1985). Hydatid cysts have been recovered from many species, including impalas, warthogs and zebras (Equus burchellii) (Young 1975). Possible definitive hosts of Echinococcus spp. on the farm in Lephalale are spotted hyenas (Crocuta crocuta), black-backed jackals (Canis mesomelas), African wild cat (Felis lybica) (Verster \& Collins 1966), and domestic dogs.

\section{Taenia spp.}

The larval stage of T. hydatigena is much larger than that of other species and is thus more easily identified (Verster 1969). The intermediate hosts are ruminants and pigs, whilst the final hosts are canines and other wild carnivores. In sheep the migratory tracts through the liver, commonly known as hepatitis cysticercosa, can cause the death of an animal (Reinecke 1983). No macroscopic liver pathology was noted in any of the gemsbok affected.

Taenia hyaenae utilises many ruminant species as intermediate hosts. The definitive hosts for this species are hyaenas and African wild dogs (Lycaon pictus) (Loos-Frank 2000). Spotted hyaenas, brown hyaenas (Hyaena brunnea), African wild dogs, black-backed jackals and leopards (Panthera pardus) are 
all known to frequent the farm from which these gemsbok came. Cysticerci that resemble this species in the number and shape of the rostellar hooks have previously been recovered from impalas and sable antelopes (Hippotragus niger) (Verster 1969). Macroscopically it cannot be distinguished from the cysticerci of other Taenia spp., including Taenia saginata. Only microscopically can $T$. saginata be identified by the absence of rostellar hooks, an important consideration during meat inspection. Humans are the definitive hosts for the latter cestode, which has been recovered from various game species. Larval T. saginata has been found in several hosts in Africa; for example Graber (1959) found the species in Dorcas gazelles (Gazella dorcas), red-fronted gazelles (Gazella rufifrons) and Gazella spp. in Chad, Le Roux (1937) observed it in oribis (Ourebia ourebi) in Zambia, Sousa Dias (1950) found it in Cape buffaloes (Syncerus caffer) in Angola and Nelson, Pester and Rickman (1965) in bushbuck in Kenya. Also, the metacestodes of Taenia solium have been found in warthogs in Africa (Bain 2001) and in wild boars (Sus scrofa) in Europe (Eslami \& Farsad-Hamdi 1992). It is evident that there is a potential public health risk associated with the consumption of venison infected with metacestodes.

Hydatid material of human origin collected in sub-Saharan Africa all conform to the sheep strain of E. granulosus (MacPherson \& Wachira 1997). However, this does not prove non-infectivity of other E. granulosus strains, species or subspecies to humans. Because of the seriousness of Echinococcus spp. infection, meat inspection should be thorough and the necessary precautions should be taken when handling carnivores (Young 1975).

\section{Fasciola}

Two specimens of F. hepatica were recovered from a kudu from the Nwanedi Game Reserve. Fasciola hepatica has not been described from kudus previously. As browsers, kudus are not normally exposed to aquatic vegetation and thus few get infected with trematodes (Condy 1972). Fasciola gigantica has been reported in Greater kudu on a game ranch in Zambia (Zieger et al. 1998) as well as in Rhodesia (now Zimbabwe), where kudu deaths were attributed to this parasite (Condy 1972; Hammond 1972). Kudus appear to be very susceptible to infection (Condy 1972).

The Nwanedi Nature Reserve, where the infected kudu was examined, has a large dam that is fed by the Nwanedzi river. This creates a favourable environment for the freshwater snail that serves as intermediate host to the flukes. Domestic stock have previously had access to the reserve and are currently kept upstream from the dam, which could be a possible source of contamination. Wildlife that have been introduced to the reserve are other possible sources. Fasciola gigantica is the most common liver fluke in domestic ruminants in Africa and accounts for most liver fluke infections in wild animals (Hammond 1972).

\section{Conclusion}

The aim of the study was to describe the helminth parasites of the common wildlife species in the northern and western parts of the Limpopo province. The climate of these areas is harsh and dry, with a large region that is considered to be semi-arid. This has an impact on the prevalence of the parasites that occur in these areas. In total 36 animals were examined and their helminths recorded. New host records for species include $A$. gorgonis in black wildebeest, $S$. globipunctata in waterbuck and F. hepatica in kudu.

For the study area as a whole, comparisons with other studies provided valuable information. The total burdens and species variation of especially the adult helminths in this study were consistently lower compared with studies in areas with higher rainfall.

The only trematode recovered was F. hepatica from a kudu at Nwanedi. The dry climate is not conducive to the survival of freshwater snails that act as intermediate hosts. These parasites typically occur in areas with wetter or more humid conditions.

There are practical implications for the low prevalence and species variation of helminths. When animals are translocated from the drier parts of the Limpopo province to areas with higher rainfall, they will be relatively naive to the higher parasite loads in those areas and/or completely naive to other parasites, such as lungworms. On the other hand, animals originating from areas with higher rainfall are likely to harbour higher parasite loads. They should be dewormed prior to translocation to dry areas, because the stress of the dry climate and change in vegetation can cause them to succumb to the parasite loads they already harbour. At the same time, new parasites could be introduced, with variable results to the wildlife already present.

Game is kept together with domestic stock on many farms in the province. Helminths that typically occur in domestic stock were recovered from some antelope species. Haemonchus contortus was recovered from all the kudus and blue wildebeest from Langgedachte. High stocking densities of animals on this farm likely contributed to the frequency of cross-transmission of parasites between species. With parasites that have a high fecundity, such as Haemonchus or Oesophagostomum, environmental build-up may become considerable under certain conditions or specific times of the year. This will impact on worm control programmes for domestic animals, but may also cause morbidity in game at times.

Some parasites are more problematic in intensive situations, for example when animals are kept in a boma or very small camps. This is especially true for parasites with a monoxenous life cycle such as Trichuris spp. Animals that are kept intensively should be dewormed to prevent environmental 
build-up of the parasite. Under extensive conditions, these parasites are unlikely to cause any problems.

The only known zoonotic helminth recovered was $E$. granulosus from the lungs of a warthog. The infective stage for humans is the egg that is deposited by the final host - dogs - which are often fed uncooked offal. One should be aware that the parasite can become established in the local human population through this route, especially in communal areas where people live in close association with their animals.

Cysticerci of $T$. hyaenae and T. hydatigena were recovered from the gemsbok. Although these tapeworms are not known to be zoonotic, the cysticerci are not macroscopically distinguishable from the zoonotic cysticeri of T. solium or T. saginata. This has public health implications because the cysticerci render the meat aesthetically unacceptable and, in addition, a lack of proof of non-infectivity does not prove that these cestodes are not in fact infective to humans.

The host species included in the study are some of the more common ones that occur on game farms in the Limpopo province. The parasites of many wildlife species, including relatively common species such as giraffes (Giraffa camelopardalis), common reedbuck (Redunca arundinum) (Boomker et al. 1984) and grey rhebuck (Pelea capreolus) (see Boomker et al. 2000) but also scarcer game such as red duikers (Cephalophus natalensis) (see Boomker et al. 1984), have not been studied extensively, particularly in the Limpopo province. Because these animals all share the same, mostly confined environment, scientific game farming practices require more knowledge on the parasites, including the helminths, of these species.

\section{Acknowledgements}

The project was funded partly by a study bursary from the Department of Agriculture, Limpopo. The late Mr. Ryno Watermeyer from the Helminthology section at the Department of Veterinary Tropical Diseases and Ms. I. Venter of the Louis Trichardt State Veterinary Laboratory are thanked for their technical assistance. Thanks also go to Mr. R. van Wyk of the Musina Research Station, Mr. S. Joubert of Kerneels Young Trust, Mr. M. Vermaas of Langgedachte, Mr. N. van Zyl of Bushman's Safaris and Mr. C. van Heerden, for making material available.

\section{Competing interests}

The authors declare that there were no competing interests that may have inappropriately influenced the presentation of information in this paper.

\section{Authors' contributions}

I.C.v.W. conducted the study in partial fulfillment of an MSc degree. J.B. acted as supervisor for the thesis and made conceptual and editorial contributions.

\section{References}

Acocks, J.P.H., 1988, Veld types of South Africa. Botanical Research Institute, Pretoria (Memoirs of the Botanical Survey of South Africa, no. 57)

Anderson, I.G., 1992, 'Observations on the life-cycles and larval morphogenesis of and transmission experiments with Cooperioides hamiltoni and Cooperioides hepaticae (Nematoda: Trichostrongyloidea) parasites in impala, Aepyceros melampus', South African Journal of Zoology 27, 81-87.

Bain, R.K., 2001, 'Africa', in N. Chowdury \& A.A. Aguierra (eds.), Helminths of wildlife, pp. 371-424, Science Publications, Enfield.

Boomker, J., 1977, 'A revision of the genus Impalaia Mönnig, 1924', Onderstepoort Journal of Veterinary Research 44, 131-138. PMid:614530

Boomker, J., Keep, M.E., Flamand, J.R. \& Horak, I.G., 1984, 'The helminths of various antelope species from Natal', Onderstepoort Journal of Veterinary Research 51, 253-256.

Boomker, J., Horak, I.G. \& De Vos, V., 1986, 'The helminth parasites of various artiodactylids from some South African nature reserves', Onderstepoort Journal of Veterinary Research 53, 93-102. PMid:3725333

Boomker, J., Anthonissen, M. \& Horak, I.G., 1988, 'Parasites of South African wildlife. II. Helminths of kudu, Tragelaphus strepsiceros, from South West Africa/Namibia', Onderstepoort Journal of Veterinary Research 55, 231-233. PMid:3217096

Boomker, J., Horak, I.G. \& De Vos, V., 1989, 'Parasites of South African wildlife. IV Helminths of kudu, Tragelaphus strepsiceros, in the Kruger National Park', Onderstepoort Journal of Veterinary Research 56, 111-121. PMid:2748130

Boomker, J. \& Reinecke, R.K., 1989, 'Trichostrongylus deflexus n. sp. (Nematoda: Trichostrongylidae) from several antelope species', South African Journal of Wildlife Management 19, 21-25.

Boomker, J., Horak, I.G., Booyse, D.G. \& Meyer, S., 1991a, 'Parasites of South African wildlife. VIII. Helminth and arthropod parasites of warthogs, Phacochoerus aethiopicus, in the Eastern Transvaal', Onderstepoort Journal of Veterinary aethiopicus, in the Eastern Transvaal,
Research 58, 195-202. PMid:1923382

Boomker, J., Horak, I.G. \& Knight, M.M., 1991b, 'Parasites of South African wildlife. IX. Helminths of kudu, Tragelaphus strepsiceros, in the Eastern Cape Province', Onderstepoort Journal of Veterinary Research 58, 203-204. PMid:1923383

Boomker, J., Horak, I.G., Watermeyer, R. \& Booyse, D.G., 2000, 'Parasites of South African wildlife. XVI. Helminths of some antelope species from the Eastern and Western Cape Provinces', Onderstepoort Journal of Veterinary Research 67, 3141. PMid: 10843320

Boomker, J., 2007, Helminth infections: Wildlife. University of Pretoria, Pretoria.

Condy, J.B., 1972, 'Observations on levels of internal parasites in free living Rhodesian wild life. I. Kudu (Tragelaphus strepsiceros [Pallas, 1926])', Zoologica Africana 7 , 413-418.

Eslami, A. \& Farsad-Hamdi, S., 1992, 'Helminth parasites of wild boar, Sus scrofa, in Iran', Journal of Wildlife Diseases 28, 316-315. PMid:1602589

Gallivan, G.J., Barker, I.K., Alves, R.M.R., Culverwell, J. \& Girdwood, R., 1989 'Observations on the lungworm, Pneumostrongylus calcaratus, in impala (Aepyceros melampus) from Swaziland', Journal of Wildlife Diseases 25, 76-82. PMid:2915405

Gallivan, G.J., Barker, I.K., Culverwell, J. \& Girdwood, R., 1996, 'Prevalence of hepatic helminths and associated pathology in impala (Aepyceros melampus) in Swaziland', Journal of Wildlife Diseases 32, 137-141. PMid:8627927

Gibbons, L.M., Jones, A. \& Khalil, L.F., 1996, Eighth international training course on identification of helminth parasites of economic importance, International Institute of Parasitology, St. Albans.

Graber, M., 1959, La cysticercose bovine. Son importance dans les zones sahéliennes d'elevage de la Republique du Tschad. [Bovine cysticercosis. Its importance in the Sahelian areas of livestock of the Republic of Chad]. Revue Êlevage de Médicine vétérinaire Pays tropicale 12, 121-143.

Hammond, J.A., 1972, 'Infections with Fasciola spp. in wildlife in Africa', Tropical Animal Health 4, 1-13. http://dx.doi.org/10.1007/BF02357089, PMid:4671397

Heinichen, I.G., 1973, 'Parasitological studies on impala: preliminary report', Journal of the South African Veterinary Association 44, 265-269. PMid:4787763

Horak, I.G., 1978, 'Parasites of domestic and wild animals in South Africa. X. Helminths of impala', Onderstepoort Journal of Veterinary Research 45, 221-228. PMid:572950

Horak, I.G., 1980, 'The incidence of helminths in pigs, sheep, cattle, impala and blesbok in the Transvaal', PhD thesis, Dept. of Zoology and Entomology, University of Natal.

Horak, I.G., 1981, 'Host specificity and the distribution of the helminth parasites in sheep, cattle, impala and blesbok according to climate', Journal of the South African Veterinary Association 52, 201-206. PMid:7310791

Horak, I.G., Biggs, H.C., Hanssen, T.S. \& Hanssen, R.E., 1983a, 'The prevalence of helminth and arthropod parasites of warthog, Phacochoerus aethiopicus, in South West Africa/Namibia', Onderstepoort Journal of Veterinary Research 50, 145-148. PMid:6634088

Horak, I.G., De Vos, V. \& Brown, M.R., 1983b, 'Parasites of domestic and wild animals in South Africa. XVI. Helminth and arthropod parasites of blue and black wildebeest (Connochaetes taurinus and Connochaetes gnou)', Onderstepoort Journal of Veterinary Research 50, 243-255. PMid:6676686

Horak, I.G., Boomker, J., De Vos, V. \& Potgieter, F.T., 1988, 'Parasites of domestic and wild animals in South Africa. XXIII. Helminth and arthropod parasites of warthogs, Phacochoerus aethiopicus, in the Eastern Transvaal Lowveld', Onderstepoort Journal of Veterinary Research 55, 145-152. PMid:3194114

Le Roux, P.L., 1937, Annual report of the Veterinary Department, Northern Rhodesia 1936, Appendix C, pp. 62-63, Government Printer, Livingstone. 
Loos-Frank, B., 2000, 'An up-date of Verster's (1969) 'Taxonomic revision of the genus Taenia Linnaeus' (Cestoda) in table format', Systematic Parasitology 45, 155-183. http://dx.doi.org/10.1023/A:1006219625792, PMid:10768761

MacPherson, C.N.L., 1985, 'Echinococcus infections in wild animals in Africa', in S. MacMillan (ed.), Proceedings of a conference on wildlife/livestock interfaces on rangelands, Taita Hills, Kenya, April 22-25, 1985, pp. 73-78.

MacPherson, C.N.L. \& Wachira, T.W.M., 1997, 'Cystic echinococcosis in Africa south of the Sahara', in F.L. Andersen, H. Ouhelli \& M. Kachani (eds.), Compendium on cystic echinococcosis in Africa and in Middle Eastern countries with specia reference to Morocco, pp. 245-277, Brigham Young University, Provo.

Mönnig, H.O., 1933, 'Wild antelopes as carriers of nematode parasites of domestic ruminants - Part III', Onderstepoort Journal of Veterinary Science and Animal Industry 1, 77-92.

Nelson, G.S., Pester, F.R.N. \& Rickman, R., 1965, 'The significance of wild animals in the transmission of cestodes of medical importance in Kenya', Transactions of the Royal Society of Tropical Medicine and Hygiene 57, 507-524. http://dx.doi. org/10.1016/0035-9203(65)90153-7

Ortlepp, R.J., 1937, 'Whipworms from South African ruminants', Onderstepoort Journal of Veterinary Science and Animal Industry 9, 91-100.

Ortlepp, R.J., 1962, 'Lungworms from South African antelopes', Onderstepoort Journal of Veterinary Research 29, 173-181.

Ortlepp, R.J., 1964, 'Observations on helminths parasitic in warthogs and bushpigs', Onderstepoort Journal of Veterinary Research 31, 11-38.

Pletcher, J.M., Horak, I.G., De Vos, V. \& Boomker, J., 1988, 'Hepatic lesions associated with Cooperioides hepaticae (Nematoda: Trichostrongyloidea) infection in impala (Aepyceros melampus) of the Kruger National Park', Journal of Wildlife Diseases 24, 650-655. PMid:3193559
Reinecke, R.K., 1983, Veterinary helminthology, Butterworth, Pretoria.

Round, M.C., 1968, 'Check list of the helminth parasites of African mammals of the orders Carnivora, Tubulidentata, Proboscidea, Hyracoidea, Artiodactyla and Perissodactyla', Technical Communication of the Commonwealth Bureau of Helminthology 38, pp. vi and 252.

Sousa Dias, V.A., 1950, Nota prévia sôbre os parasitas dos animais domésticos de Angola. [Notes on the prevalence of parasites of domestic animals in Angola]. Pecuária: anais dos Serviços de Veterinária e Indústria Animal da Colónia de Angola 2, 53-59.

South African Weather Service, 2007, Rainfall $(\mathrm{mm})$ for the season July 2006 to June 2007, viewed 10 October 2007, from http://www.weathersa.co.za/RainfallMaps/.

Verster, A. \& Collins, M., 1966, 'The incidence of hydatidosis in the Republic of South Africa', Onderstepoort Journal of Veterinary Research 33, 49-72. PMid:600778

Verster, A., 1969, 'A taxonomic revision of the genus Taenia Linnaeus, 1758', Onderstepoort Journal of Veterinary Research 36, 3-58. PMid:5407584

Young, E., 1975, 'Echinococcosis (hydatidosis) in wild animals of the Kruge National Park', Journal of the South African Veterinary Association 46, 285-286. PMid:1219111

Young, E. \& Wagener, L.J.J., 1968, 'The impala as a source of food and by-products. Data on production potential, parasites and pathology of free-living impalas in the Kruger National Park', Journal of the South African Veterinary Medical Association 39, 81-86.

Zieger, U., Boomker, J., Cauldwell, A.E. \& Horak, I.G., 1998, 'Helminths and botfly larvae of wild ungulates on a game ranch in Central Province, Zambia', Onderstepoort Journal of Veterinary Research 65, 137-141. PMid:9741058 